\section{B A Institute of \\ YK Business Administration \\ 六下 \\ Karachi \\ Leadership and Ideas for Tomorrow}

Business Review

Volume 4 Issue 2 July-December 2009

$1-7-2009$

\title{
Incorporation of total quality management tools in higher education: A theoretical model
}

Samina Rafat

Institute of Productivity and Management, Lucknow, U.P, India

Shikha Sahai

Institute of Productivity and Management, Lucknow, U.P, India

Follow this and additional works at: https://ir.iba.edu.pk/businessreview

Part of the Higher Education Commons

c) (i)

This work is licensed under a Creative Commons Attribution 4.0 International License.

\section{Recommended Citation}

Rafat, S., \& Sahai, S. (2009). Incorporation of total quality management tools in higher education: A theoretical model. Business Review, 4(2), 55-68. Retrieved from https://doi.org/10.54784/1990-6587.1331 


\title{
ARTICLE
}

\section{Incorporation of Total Quality Management Tools in Higher Education: A Theoretical Model}

\author{
Samina Rafat, Shikha Sahai \\ Institute of Productivity and Management, Lucknow, U.P, India
}

\begin{abstract}
In the context of higher education, striving for high quality is not a new strategy. Institutions have always held academic excellence and high quality as the highest goals. Achieving these goals was easier in a time of abundant resources and favorable demographics. But the environment has changed now. Institutions are now facing decreasing enrollments and revenues while costs and competition for students are increasing. There is an ever-rising need to satisfy the students with quality education in order to attract, develop and retain them. To address the above issue we propose a model for incorporating total quality management tools in higher education. The model introduced in this research paper is based on the systems approach to Total Quality Management. It first puts forward the key determinants of the Input, Process and Output for 'The Education System' and it then incorporates Total Quality Management Tools for all these important determinants.
\end{abstract}

KEYWORDS: TQM, Systems Approach, Higher Education JEL CODE: M00

\section{INTRODUCTION}

Education Sector is in the transition phase all over the world. Avdjieva and Wilson (2002) suggest, Higher Education Institutions (HEIs) which are regarded as organizations of learning are now required to become learning organizations, where internal stakeholders also interpret and assess the quality of higher education provision. There is a shift away from old models where students were considered as passive recipients of teachers, absorbing information in an uncritical way to a growing enthusiasm for active, independent learning, which encouraged participation, questioning and reasoning. The modern educators believe that education is not just meant to impart knowledge and information but it should also incorporate the attitude of life long learning amongst the students. To maintain these expectations of modern times, the quality has become the key to success for all the educational institutions. It is for this reason that TQM wave has finally hit the higher education sector. 


\section{REVIEW OF LITERATURE}

Total Quality Management (TQM) is a management philosophy that focuses on perpetual process enhancement through the prevention of problems and errors. It requires continual monitoring and control process, performance and quality, the placing of the customer at the summit of attention as well as a sense of awareness, commitment and involvement on the part of management, all the workers, the customers and suppliers (Waks and Moti, 1999).

Lewis and Smith (1994) with a closer perspective to higher education, define TQM as a concept introduced by business and industry to establish standards and techniques that ensure the quality of products leaving and reaching firms through continuous actions rather than through one final inspection. It relies on the experiences, expertise and commitment of all members of an organization to improve the process by which customers are served.

Harvey and Knight (1996) suggest that quality can be broken down into five different but related dimensions: quality as exceptional (e.g. high standards), quality as consistency (e.g. zero defect) quality as fitness for purpose (fitting customer specifications, quality as value for money and quality as transformative (an ongoing process that includes empowerment and enhancement of the customer satisfaction). Engelkemeyer (1993) categorizes the shortcomings of the present higher education system as poor teaching, anachronistic programs, incoherent curricula, excessive price and growing and inefficient administrative bureaucracies. All these factors undermine the quality of education in an institution.

There are different models built to establish TQM in the field of higher education. Pounder (2002) describes a Hong Kong study, which developed organizational effectiveness self-rating scales for higher education. Behavioral examples were generated and participants were requested to provide examples for good, average and poor institutional behavior. But the attempt to develop a one-dimensional scale for quality led to the generation of series of behavioral examples, which reflected only the specific perceptions quality held by the providers of the examples.

The paradigm shift in higher education has come up with its arguments on the appropriateness of TQM philosophy to higher education. Two of the advocates of appropriateness issue are Lewis and Smith (1994). In their book, after the discussion of the issue, they exemplify the implementation of TQM at Ohio State University. According to them, principles and concepts of total quality are compatible with the best 
tradition and practices of higher education. The underlying philosophy, values, and norms reflected in total quality and continuous improvement are appropriate to higher education. These include (1) an emphasis on service; (2) anticipating and meeting the needs and expectations of the constituents; (3) recognizing and improving transformation processes and systems; (4) implementing teamwork and collaboration; (5) instituting management based on leadership, knowledge-based decisions, and involvement; (6) solving problems based on systematic identification of facts and the use of feedback systems and statistical methods or tools; and (7) implementing a genuine respect for and development of human resources- the people who work in colleges and universities.

Similarly, Hackman and Wagerman (1995) stated that TQM as a management philosophy, has been proven to have convergent validity by way of consisting of a common set of assumptions and practices as it is being practiced in various organizations. Many TQM models, which are based on these assumptions and principles, exist in higher education institutions in many parts of the world. For the application of TQM principles in institutions of higher education, Seymour and Collett (1992) point out the varying levels of visibility among three approaches to implementation. They suggest that the high-visibility "cascade" model may be appropriate at smaller institutions where everything tends to be highly visible. Large campuses, however, are fragmented into specialized academic disciplines and autonomous centers and research units; therefore they may opt for the low-key visibility more common with the "infection" model. The "loose-tight" model, which combines low-key and high-visibility, may be most appropriate for a number of institutions that have a more "middle of the road" approach to TQM. The most important thing is that whichever implementation model is employed, it should be appropriately linked to the "Institution's mission, its culture, its strengths and weaknesses, its opportunities and threats, and the number and location of change agents and would-be champions".

Sutcliffe and Pollock (1992) allude to similar strategies as they discuss the Implementation of TQM in institutions of higher education. They suggest that "Implementation begins with the drawing up of a quality policy statement and the establishment of an organizational framework for both managing and encouraging the Involvement of all parties in attaining quality through teamwork". They recommend that all workers throughout the institution be trained in quality assurance methods, problem solving techniques, and communication and that evaluation occurs at all levels and include the customers' perceptions as well. Many other TQM models based on the TQM philosophy and principles exist in the world. 


\section{THE MODEL}

The model developed in this research paper relied on the following approaches

- Systems approach to education in which decisions are made about the input, process and output. At the broadest level, education quality can be viewed as a set of elements that constitute the input, process and output of the education system and provides services that completely satisfy both internal and external constituencies by meeting their explicit and implicit expectations (Cheng and Tam, 1997) If higher education is viewed as a system then any quality management programme must therefore assess input, process and outputs.

- Cheng and Tam (1997) also identified both internal and external stakeholders in the quality management process. Current students and front line staff are internal constituents whereas employers, government bodies, institutional management, prospective students and professional bodies are external stakeholders. These stakeholders have disparate definitions of quality as well as different preferences for how quality is assessed.

- The Model incorporates contemporary TQM tools: benchmarking, Quality audits, quality circles, empowerment, Standard of procedures, Continuous improvement, Pareto analysis.

- As for the principal and concepts, Deming's ten major categories of judgment, relevant standards of ISO 9000, specifications emancipated by All India Council For Technical Education for Technology and management led to the conceptualization process. Each determinant has been carefully examined in the sense of practicability, reasonability, attainability and research ability.

This research paper has considered higher education as a system and is mainly based on the research and analysis of current models, contemporary TQM tools that could be used by higher education services and the demands of higher education.

We now present our 'education system model', which will identify the key determinants of the education system, and then we will step by step incorporate TQM tools for all the key determinants. The TQM tools that have been used in this model are: Benchmarking, quality audits, continuous improvement, and empowerment \& Pareto analysis. 


\section{THE EDUCATION SYSTEM}

The education system is influenced by and influences the external environment. The key determinants of the external environment are the society, industry, government \& prospective students. These determinants provide input to the 'education system' in the form of personnel (students \& faculty), technology (support material \& equipment) $\&$ finance (Capital). The inputs go into the transformation process whereby they have to pass through a rigorous curriculum design $\&$ development, delivery (delivery comes through Essential services delivered by faculty, facilitating Services \& Supporting Services) and development of the two important resources of the institution (Students $\&$ faculty). This systems output are in the form of non-monetary gain (enlightened society) environment), students career progression \& faculty career progression \& profit to the institution \& non-monetary). This system like any other systems is enriched with a feedback mechanism.

The Following are the determinants of The INPUT-THROUGHPUT-OUTPUTFEEDBACK of an education system:

a) Input of

- Students \& Faculty

- Technology

- Capital

b) Throughput (Transformation process) through

-- Curriculum Design \& Development

-- Delivery is through

- Essential Services (Faculty imparting Knowledge Skills \& Attitude to students)

- Facilitating Services (Management/ Administration, Placements, Library, Computer Labs \& other labs)

- Support Services (House Keeping, counseling, Service Scape) -- Development is through

- Students development programmes

c) Out put of

- Faculty Development programmes

- Enlightened Society

- Students Career progression \& Faculty Career progression

- Profit To The Institution 
d) Feedback is through

- Satisfaction Survey of Students, Parents, Alumni \& Industry

Now we would discuss only the key determinants of the INPUT-PROCESSOUTPUT of the education system where we have suggested TQM tools for quality improvement:

\section{Entry of Students (Input)}

Student at the input stage has just joined the 'system'. The role of TQM is to apply stringent procedure, which involves thorough screening and sieving of the candidates before selecting him. The important determinants that need to be taken into consideration are:

- Past Academic Performance

- Knowledge cum Aptitude Tests

- Demographic profile including Age, Past Work Experience \&

- Personal Interview

\section{Entry of Faculty (Input)}

For selecting the team of knowledge disseminators (faculty) institutions should make the recruitment of faculty members by selecting the best of the talents from the industry. For this they need to consider following parameters

- Job Description \& Job Specification

- Demography

- Psychograph

- Past Experience

- Performance Test

- Academic Achievements

\section{Curriculum Design \& Development (Transformation process)}

Main elements of Curriculum Design \& Development include:

- Programme Structure

- No. Of semesters in each year

- No. Of papers in each semester

- Course syllabi of each paper 
The role of TQM at this stage would mean developing contemporary programmes and courses that are revised periodically by benchmarking industries needs \& expectations.

\section{Essential Services (Delivery)}

Disseminating knowledge, imparting skills and building positive attitude are the Essential Services to be provided to the students (customers). The key resource providing these essential services is the core faculty of the institutions and hence the institution needs to concentrate the most on the quality of its faculty. This requires recruiting the best of the faculty members from the industry, continuous up gradations and development of the faculty members and a close interaction between the faculty members and the management of the organization. Continuous progression and monitoring of faculty is a must to deliver the service (education here). Faculty progression and monitoring has been discussed later in the paper.

\section{Facilitating Services (Delivery)}

Facilitating services include management/ administration, library, computer labs and other labs (IF any). Now we discuss the key determinants of these facilitating services and we suggest TQM tools for improving their quality.

\section{a) Management/Administration}

On the one hand management is an important stakeholder of the education system and on the other the successful running of the institution is dependent on a visionary management. The key determinants of management/administration are:

- Aligning Vision, mission and objectives of the organization with the changing market demands

- Administration of students, faculty and other staff

- Balancing the flow of Communication:

- Decision making

- Directing \& controlling

- TQM tools for this variable would mean

- Quantification of objectives and goals to be achieved

- Open communication

- Decentralization of power

- Assessment and changes in organizational culture 
- Faculty administration through audits on number of hours spent on teaching, on research, attendance and late coming

- Student's administration through audits on attendance, obedience and late coming.

\section{b) Placements}

Placements of students are a very important determinant for the success of any higher education system. The key variables to assess the success of placement services include:

- Number of companies that visited the campus

- Number of jobs offered

- Average minimum and maximum salary's offered

- Number of students joining universities and further research.

- TQM for this variable would mean continuous improvement in both and number of company's visiting, as well as in terms of salary.

\section{c) Library}

A dynamic library is the demand of any modern institution. It is meant to provide/ supplement the classroom learning. The key determinants of the library function are

- Books in adequate numbers

- Variety of books by different authors

- Continually growing library

- Arrangement of books

- The TQM tool for this include

- Introduction of electronic library,

- Benchmarking library softwares

- Quality audits on number of books and authors/ journals

- Number of books/ journals added per annum

- Number of damaged/ unreturned books and journals,

- Space utilizations.

d) Computer Lab: In the, modern learning institutions it is impossible to imagine imparting knowledge without the use of computers. The TQM tools for this service would include 
- Benchmarking the hardwares and softwares available in the market

- Maintaining a low student to PC ratio

- Similarly other labs like science labs, behavioral labs need to benchmark the equipments as well as the availability of the equipments for the students.

\section{6) Support Services (Delivery)}

Support services include continuous supply of counseling, housekeeping (electricity, photocopy machine, instructional equipments, stationery, and automated centralized telephone lines) and servicescape

TQM tools for support services are

- Quality audit to assess the current status of the support services

- Benchmarking the support services available in external environment

\section{a) Counseling Cell}

Counseling has become one of the essential services of an educational institution, it is meant to help advice and guide the students/ parents solve in solving student specific problems.

TQM for them would mean Audits and continuous improvements on

- Number of problems raised be students

- Number of students raising problems

- Number of problems solved

\section{b) House Keeping}

House keeping is maintenance of the property and equipments of the institution. TQM for housekeeping would mean establishing quality circles that would keep a check on the determinants of housekeeping and would identify quality related problems with them and even solve those problems.

\section{c) Servicescape}

Servicescape includes both the exterior and interior décor of the institution. The key determinant of servicescape include 
- External

- Building

- Landscape

- $\quad$ Parking Area

\section{- Internal}

- Ambience

- Décor

- Air temperature

- Humidity

- Physical Layout

- Signage

TQM for servicescape would mean Quality Audits, Quality Circle \& continuous improvement in both the external and internal scape keeping cost constraints into consideration.

7) Monitoring (Transformation)

a) Student Development Programmes

- Behavioral \& Attitudinal training

- Personality development programmes

b) Faculty development Programmes to include

- Training on the new Theories \& principles of the concerned subject

- Training on the new pedagogy system

- Training on the new technology and its use in teaching

TQM for the above variables are: Histograms to compare frequency of the present development programmes with the previous development programmes for both faculty as well as students; Quality circles of students and faculty can be formed to assess the improvements required in the quality of programmes delivered to them.

8) Student progression is to be monitored on the following

- Assimilating knowledge

- Ability to use the knowledge assimilated

- Development of skills \& competency relevant to the programme /curriculum for which the student has enrolled himself.

- Development of positive attitude 
Student progression is reflected through

- Marks

- Pass Percentage

- Maximum, minimum and average marks of the students

- Drop outs

- Failure Rate

- Employment Achievement

- No of students employed

- No. Of students who opted for further research

- Maximum, minimum \& average salaries earned by the passing out students

- $\quad$ Students (Alumni's) Career Progression

- Positions held/ promotions Received

- Percentage increase in income.

TQM for these variables would mean preparation of histograms and statistical bar graphs to find the trends (increase/ decrease from the previous years) in marks, success rate, drop out rate, number of jobs offered, change in the salary offered, no of students joining research/ jobs.

\section{9) Faculty Career progression}

Faculty career progression is done on the basis of following criteria

- No. of hours spent on teaching \& on research

- No of research papers \& books published

- No. of Faculty Development Programmes attended

- No. of papers presented in various seminars and conferences

TQM at this stage would mean audit of all the parameters mentioned above so that faculty can prepare their academic plan for the next year.

\section{0) Feedback}

Feedback is considered as a very important part of any system, feedback for education system would mean assessing the satisfaction level of students, parents, alumni and employers (who had recruited institutes students). TQM at this level could mean 
development of Pareto Charts: in which the problems are being categorized from the least to the most. A number of problems will have common cause and when these common causes are plotted together on a histogram it can be seen that there are a few causes that are responsible for many problems. Once common cause of number of problems is being identified steps can be taken to overcome these problems.

\section{CONCLUSION}

Total Quality Management (TQM) is a management philosophy that focuses on perpetual process enhancement through the prevention of problems and errors. It requires continual monitoring and control process, performance and quality, the placing of the customer. Total Quality Management (TQM) is an important movement that has gained increasing interest and application even in higher education over the past few years. Though several tools have been used to implement TQM in higher education but there is no systematic approach to implement it in the entire institution. Hence a pervasive model has been presented to implement TQM in higher education.

The model presented above considers 'education system' as an open system, which has permeable boundaries, and hence it affects and gets affected by the external boundary. The model has incorporated TQM only in those elements where the results would help in overall growth \& sustainable development of an institution. The TQM tools used in the model range from: benchmarking, continuous improvement, quality audit, quality control, empowerment, histogram \& pareto charts. It should be noted here that incorporating quality tools in higher education is a site-specific issue although there are some standards and procedure common to all. Quality assurance is not a concept having accepted as right or wrong. Each institution would establish its own methods and standards, however it is stated here that the comprehensive model can be used as a reference standard by management of higher education in which lies the significance of the model presented above.

\section{Knowledge is All}

The Next Society will be a knowledge society. Knowledge will be its key resource, and knowledge workers will be the dominant group in its workforce. Its three main characteristics will be:

- Borderlessness, because knowledge travels even more effortlessly than money.

- Upward mobility, available to everyone through easily acquired formal education.

- The potential for failure as well as success. Anyone can acquire the "means of production," i.e., the knowledge required for the job, but not everyone can win. P.F. Drucker: Managing in the Next Society, PP. 237-238 


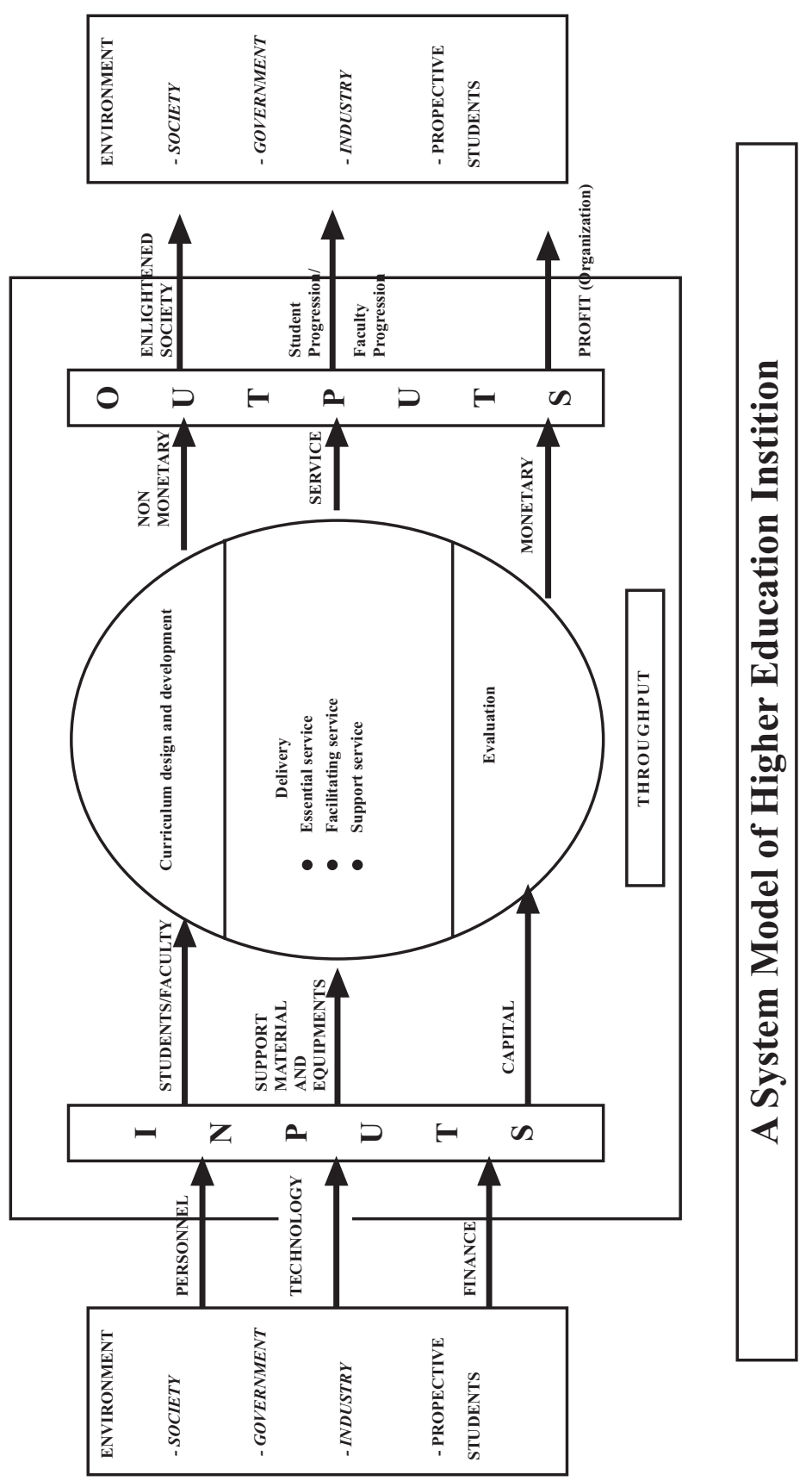




\section{REFRENCES}

Avdjieva, M and Wilson M, (2002), Exploring the Development of Quality in Higher Education, Managing Services Quality, 2(6), pp 372-383.

Cheng, YC and Tam WM (1997), Multi Model of Quality in Higher Education, Quality Assurance in Education, 5(1), pp 22-31.

Crumrine, B. and Runnels, T. (1991), Total Quality Management in Vocational-Tenchinal Education, Norman, OK: Moore-Norman Vo-Tech Center, (ED 340 846)

Deming, WE (1986), Out of the Crisis, Cambridge: MIT Centre for advance engineering study.

Engelkemeyer, S.W. (1993), TQM in higher education, The Centre for Quality Management Journal, 2(1), pp 28-33.

Hackman, JR \& Wagerman, R (1995), Total quality Management: empirical, conceptual and practical issues , Administrative Science Quarterly, 40 pp 309-342.

Harvey L \& Knight PT (1996), Transforming Higher Education, Buckingham: SRHE and Open University Press.

Lewis, RG \& smith, HD (1994), Total Quality Management in Higher Education, St. Lucie Press, Florida.

Becket, N., Brookes, M. (2005), Analysing quality audits in higher education. Oxford Brookes University eJournal of Public Sector Management, 15 (6),pp 458-474.

Pounder J.S. (2002), Public accountability in Hong Kong higher education: Human resource management implications of assessing organizational effectiveness, International Journal of Public Sector Management, 15 (6), pp 458-474.

Seymour, D and Collett, C (1992) “Total Quality Management in higher education: A critical assessment. Methuen: MA: Global/QPC.

Sutcliffe, W., and Pollock J., Can the Total Quality Management Approach Used in Industry Be Transferred to Institutions of Higher Education? Vocational Aspect of Education, 44, no. a (1992): pp11-27.

Waks, S and F Moti (1999), Application of the Total Quality Management principles and ISO 9000 standards in engineering education, European Journal of engineering Education, 24(3), pp 249-259. 